\title{
Changes in Neuropeptide Y Receptors and Pro-Opiomelanocortin in the Anorexia (anx/anx) Mouse Hypothalamus
}

\author{
Christian Broberger, ${ }^{1}$ Jeanette Johansen, ${ }^{2}$ Hjalmar Brismar, ${ }^{3}$ Carolina Johansson, ${ }^{2}$ Martin Schalling, ${ }^{2}$ and \\ Tomas Hökfelt ${ }^{1}$
}

Departments of ${ }^{1}$ Neuroscience, ${ }^{2}$ Molecular Medicine, and ${ }^{3}$ Woman and Child Health, Karolinska Institutet, 17177 Stockholm, Sweden

The pro-opiomelanocortinergic (POMCergic) system originating in the hypothalamic arcuate nucleus extends projections widely over the brain and has been shown to be intricately linked and parallel to the arcuate neuropeptide Y (NPY) system. Both NPY and POMC-derived peptides (melanocortins) have been strongly implicated in the control of feeding behavior, with the former exerting orexigenic effects and the latter having anorexigenic properties. Mice homozygous for the lethal anorexia (anx) mutation are hypophagic, emaciated, and exhibit anomalous processing of NPY exclusively in the arcuate nucleus, providing an interesting model to study NPY-POMC interactions. In the present study, several morphological markers were used to investigate the histochemistry and morphology of the POMC system in anx/anx mice. In situ hybridization demonstrated decreased numbers of POMC mRNA-expressing neurons in the anx/anx arcuate nucleus. In parallel, mRNA levels for both the
NPY $Y 1$ and $Y 5$ receptors, which are expressed in POMC neurons, were decreased. Also, expression of the NPY Y2 autoreceptor was attenuated. Immunohistochemistry using antibodies against adrenocorticotropic hormone to demonstrate POMC cell bodies, against $\alpha$-melanocyte-stimulating hormone to demonstrate axonal projections and against the NPY Y1 receptor to demonstrate dendritic arborizations, showed strikingly decreased immunoreactivities for all these markers. The present data suggest that degeneration of the arcuate POMC system is a feature characteristic of the anx/anx mouse. The possible relationship to the NPYergic phenotype of this animal is discussed.

Key words: adrenocorticotropic hormone; $\alpha$-melanocytestimulating hormone; arcuate nucleus; feeding; immunohistochemistry; in situ hybridization; paraventricular nucleus of the hypothalamus; trophism
The neurochemical basis for the central control of food intake has been illuminated by recent investigations (Leibowitz, 1995; Sawchenko, 1998; Woods et al., 1998; Elmquist et al., 1999; Kalra et al., 1999). Two messenger molecules expressed in discrete populations of the hypothalamic arcuate nucleus appear to play antagonistic roles in energy balance control, namely neuropeptide Y (NPY) (Tatemoto, 1982; Tatemoto et al., 1982) and proopiomelanocortin (POMC) (Mains et al., 1977; Roberts and Herbert, 1977; Nakanishi et al., 1979), the precursor protein for the melanocortin peptides adrenocorticotropic hormone (ACTH) and $\alpha$-melanocyte-stimulating hormone $(\alpha-\mathrm{MSH})$. Intracerebral injections of NPY stimulate food intake (Clark et al., 1984; Stanley and Leibowitz, 1985), whereas melanocortin treatment induces anorexia (Poggioli et al., 1986; Fan et al., 1997; Grill et al., 1998), and mice deficient for the melanocortin-4 receptor develop obesity (Huszar et al., 1997). Furthermore, fasting increases arcuate NPY mRNA levels and decreases POMC mRNA (Brady et al., 1990).

\footnotetext{
Received Feb. 11, 1999; revised April 28, 1999; accepted June 3, 1999.

This study was supported by the Swedish Medical Research Council (Grants 14X-2887 and 13X-10909 for T.H. and M.S., respectively), Marianne and Marcus Wallenberg's Foundation, a Bristol-Myers Squibb Unrestricted Neuroscience grant to T.H., National Alliance for Research on Schizophrenia and Depression, and funds from Karolinska Institutet and the Karolinska Hospital. We thank Drs. John Walsh and Helen Wong, (CURE, University of California at Los Angeles, Los Angeles, CA) for kindly providing Y1 receptor antiserum (antibody/Radioimmunoassay Core Grant DK41301).

Correspondence should be addressed to Dr. Christian Broberger, Department of Neuroscience, Karolinska Institutet, 17177 Stockholm, Sweden.

Copyright (C) 1999 Society for Neuroscience $0270-6474 / 99 / 197130-10 \$ 05.00 / 0$
}

The projections of the arcuate NPY and POMC neurons follow seemingly parallel routes (Broberger et al., 1998b) and may terminate on common postsynaptic targets. NPY neurons also innervate the POMC cell bodies, which express the inhibitory NPY Y1 receptor (Y1R) (Csiffáry et al., 1990; Zhang et al., 1994; Broberger et al., 1997b; Fuxe et al., 1997). A similar expression pattern has been suggested for the Y5 receptor (Y5R) (Gerald et al., 1996; Naveilhan et al., 1998a). Activation of the Y1R and the Y5R (Flood and Morley, 1989; Stanley et al., 1992; Gerald et al., 1996) stimulates food intake, possibly through inhibition of POMC signaling. In addition, NPY neurons also express agouti gene-related protein (AGRP) (Shutter et al., 1997; Broberger et al., 1998a,b; Hahn et al., 1998), an antagonist of the melanocortins (Ollmann et al., 1997). Thus, both anatomical and pharmacological evidence suggest that the balance between NPY and POMC transmission may be correlated to the level of food intake.

The anorexia (anx) mutation is a recessive autosomal mutation in mice that phenotypically results in decreased food intake, emaciation, and premature death during the fourth postnatal week (Maltais et al., 1984). A possible explanation for this phenotype was provided by the recent demonstration of NPY abnormalities in anx/anx mice that appear to be restricted to the arcuate system, characterized by a decrease in the number of its NPYimmunoreactive (-IR) nerve terminals and a strongly increased perikaryal staining in the arcuate nucleus, a pattern suggestive of cell body accumulation and impaired transport and/or release (Broberger et al., 1997a). The same pattern was also noted with AGRP histochemistry (Broberger et al., 1998b). In accordance with the orexigenic function of arcuate NPY neurons described 
above, diminished NPY-AGRP signaling could be causally related to the anorectic phenotype of anx/anx mice.

The present study investigated the histochemistry of POMC neurons in anx/anx mice, using several markers expressed by this population, to gain understanding of how the melanocortinergic system functions in a potentially "hypoNPYergic" state. These markers include mRNAs for POMC, the Y1R and the Y5R studied by in situ hybridization, as well as ACTH, $\alpha-\mathrm{MSH}$, and the Y1R studied by immunohistochemistry. We have also investigated the expression of the autoinhibitory Y2 receptor coexpressed with NPY in arcuate neurons (Broberger et al., 1997b) in anx/anx mice.

Part of these results have been presented previously in abstract form (Broberger et al., 1998c).

\section{MATERIALS AND METHODS}

Animals. Animals were housed together in ventilated cages in an animal room maintained on a $12 \mathrm{hr}$ light/dark schedule with lights on at 7.00 A.M., at a temperature of $+25^{\circ} \mathrm{C}$. The anx/anx mice were characterized genotypically using nearby located simple sequence length polymorphisms and phenotypically on the basis of body weight and neurological abnormalities determined before dissection-perfusion. Both male and female mice were analyzed. For in situ hybridization, 10 anx/anx mice and eight wild-type littermates were used. For immunohistochemistry, six anx/anx mice and seven wild-type littermates were used. Dissection was performed on postnatal days 20 or 21 . For in situ hybridization experiments, brains were dissected from decapitated animals and rapidly frozen. For immunohistochemistry, mice were anesthetized with $0.1 \mathrm{ml}$ of sodium pentobarbital (Mebumal; $6 \mathrm{mg} / \mathrm{ml}$, i.p.; Apoteksbolaget, Umeå, Sweden) and perfused via the ascending aorta with $10 \mathrm{ml}$ of $\mathrm{Ca}^{2+}$-free Tyrode's solution $\left(37^{\circ} \mathrm{C}\right)$, followed by $10 \mathrm{ml}$ of a mixture of formalin and picric acid (4\% paraformaldehyde and $0.4 \%$ picric acid in $0.16 \mathrm{~m}$ phosphate buffer, $\mathrm{pH} 6.9,37^{\circ} \mathrm{C}$ ) according to Zamboni and de Martino (1967), followed by $50 \mathrm{ml}$ of ice-cold fixative (as above). The brains were rapidly dissected out, immersed in the same fixative for $3 \mathrm{hr}$, and rinsed for at least $24 \mathrm{hr}$ in $0.1 \mathrm{M}$ phosphate buffer, $\mathrm{pH} 7.4$, containing $10 \%$ sucrose, $0.02 \%$ bacitracin (Sigma, St. Louis, MO), and $0.01 \%$ sodium azide (Merck, Darmstadt, Germany).

In situ hybridization. Brains from all animal groups were mounted together on the same chuck, frozen, and coronally sectioned at $14 \mu \mathrm{m}$ in a cryostat (Microm, Heidelberg, Germany). The sections were thawmounted onto ProbeOn slides (Fisher Scientific, Pittsburgh, PA) and then stored at $-20^{\circ} \mathrm{C}$ until processing. Oligonucleotide probes complementary to nucleotides 266-319 of the rat POMC mRNA (Drouin and Goodman, 1980), nucleotides 546-586 of the rat Y1R (Eva et al., 1990), nucleotides $737-775,1040-1081$, and $1166-1203$ of the mouse Y2R (Nakamura et al., 1996), and nucleotides 755-802, 898-945, and 11761223 of the mouse Y5R (Nakamura et al., 1997) were synthesized (Scandinavian Gene Synthesis, Köping, Sweden), 3' end-labeled with ${ }^{35} \mathrm{~S}-\alpha$-dATP (NEN, Boston, MA) using terminal deoxynucleotidyl transferase (Amersham, Buckinghamshire, UK), and purified using Qiaquick Nucleotide Removal Kit (Qiagen, Hilden, Germany). The probes had specific activities ranging between $2.5-3.8 \times 10^{6} \mathrm{cpm} / \mathrm{ng}$ oligonucleotide. In situ hybridization was performed essentially as described previously (Schalling et al., 1988; Young, 1990; Dagerlind et al., 1992). In brief, tissue sections were air-dried and incubated for $16 \mathrm{hr}$ at $42^{\circ}$ with $10^{6} \mathrm{cpm}$ of the labeled probe in a hybridization solution containing $50 \%$ deionized formamide (Baker, Deventer, The Netherlands), $4 \times$ SSC $(1 \times$ SSC: $0.15 \mathrm{~m} \mathrm{NaCl}$ and $0.015 \mathrm{~m} \mathrm{Na}$ sodium citrate), $1 \times$ Denhardt's solution, $0.02 \%$ bovine serum albumin, $0.02 \%$ Ficoll (Pharmacia, Uppsala, Sweden), $0.02 \%$ polyvinylpyrrolidone (Sigma), $0.02 \mathrm{M} \mathrm{NaPO}_{4}$ buffer, $\mathrm{pH} 7.0$, $1 \% \mathrm{~N}$-lauroylsarcosine, $10 \%$ dextran sulfate (Pharmacia), $500 \mu \mathrm{g} / \mathrm{ml}$ denatured salmon testis DNA (Sigma), and $200 \mathrm{~mm}$ dithiotreitol (LKB, Stockholm, Sweden). After hybridization, the sections were rinsed in $1 \times$ $\mathrm{SSC}$ at $55^{\circ} \mathrm{C}$ for $60 \mathrm{~min}$, including four changes of SSC, and for $60 \mathrm{~min}$ at room temperature, transferred through distilled water, dehydrated through 60 and $95 \%$ ethanol (15 sec each), and apposed to $\beta$-max autoradiography film (Amersham) at $-20^{\circ} \mathrm{C}$. After 1 day (POMC probe) or 5 weeks (Y1R, Y2R, and Y5R probes) of exposure, the films were developed with Kodak LX 24 (Eastman Kodak, Rochester, NY) for 4 min and fixed for $10 \mathrm{~min}$ in Kodak AL4. In addition to film autoradiography, sections were dipped in Kodak NTB2 autoradiography emulsion in distilled water, exposed for 1 (POMC probe) or 8 (Y1R, Y2R, and Y5R probes) weeks in light-free metal containers at $-20^{\circ} \mathrm{C}$, developed in Kodak D19 for $3 \mathrm{~min}$, and fixed in Kodak 3000 for 6-7 min. Sections were rinsed in distilled water, counterstained with cresyl violet, and coverslipped with Entellan (Merck). All sections were examined under bright- and dark-field illumination using a Nikon (Tokyo, Japan) Microphot-FX microscope. Photomicrographs were taken with Kodak T-max 100 film.

Quantification of autoradiograms. Measurements were performed on a MacIntosh IIx (Apple Computer Inc., Cupertino, CA) equipped with a Quick Capture frame grabber card (Data Translation, Marlboro, MA), a Northern Light precision illuminator (Imaging Research, St. Catharines, Ontario, Canada), and a Dage-MTI CCD-72 series camera (Dage-MTI, Michigan City, IN) equipped with a Nikon $55 \mathrm{~mm}$ lens. To process images, NIH Image software (courtesy of Wayne Rasband, National Institute of Mental Health, Bethesda, MD) was used. Each image was an average of eight video frames digitized to a $512 \times 512$ matrix with 256 gray levels for each picture element. To adjust for possible defect in the illumination or optical pathway, an image of the empty illumination screen was taken through a neutral filter and used for background shading correction. The gray levels of eight ${ }^{14} \mathrm{C}$-plastic standards (Amersham) (Miller, 1991) exposed to the autoradiography film together with the tissue sections were determined and used in a third-degree polynominal approximation to construct a gray level to activity transfer function. The borders of the measuring fields were interactively defined, and the average gray level was calculated using the Macintosh computer and Microsoft Excel (Apple). The average gray level of control tissue was set to $100 \%$, and changes in gray levels in the arcuate nucleus from sections of anx/anx mice were expressed as percentage of controls. To quantify the relative numbers of POMC mRNAexpressing neurons, one section from each animal at the level of bregma $-1.7 \mathrm{~mm}$ was chosen. Under bright-field illumination combined with epi-illumination, the total number of labeled cells in the arcuate nucleus on both sides of the third ventricle was counted. Cells were considered labeled when the number of silver grains overlying the cytoplasm exceeded five times the background levels.

Immunohistochemistry. Coronal brain sections of $14 \mu \mathrm{m}$ thickness were cut on a cryostat (Microm) and thaw-mounted onto gelatin-coated glass slides. The sections were then processed according to the catalyzed reporter deposition method, by incubating overnight with primary polyclonal antisera to $\alpha$-MSH $(1: 400$; Peninsula, Belmont, CA) or Y1R (1:2000; Broberger et al., 1997), both raised in rabbits, or ACTH (1:400; Peninsula), raised in guinea pig, at $4^{\circ} \mathrm{C}$, rinsing in PBS, followed by catalyzed reporter deposition using the Renaissance kit (DuPont NEN, Boston, MA). After $10 \mathrm{~min}$ rinsing in TNT buffer ( $0.1 \mathrm{M}$ Tris- $\mathrm{HCl}, \mathrm{pH}$ $7.5,0.15 \mathrm{M} \mathrm{NaCl}$, and $0.05 \%$ Tween 20 ), the sections were preincubated for $30 \mathrm{~min}$ at room temperature in TNB buffer $(0.1 \mathrm{M}$ Tris-HCl, $\mathrm{pH} 7.5$, $0.15 \mathrm{M} \mathrm{NaCl}$, and $0.05 \%$ DuPont Blocking Reagent) and incubated for 30 min at room temperature with horseradish peroxidase-conjugated swine anti-rabbit immunoglobulins (Dako A/S, Copenhagen, Denmark) for $\alpha$-MSH and Y1R antisera or horseradish peroxidase-conjugated rabbit anti-guinea pig immunoglobulins (Dako A/S) for ACTH antiserum, diluted at 1:100 in TNT buffer. The sections were washed three times for $10 \mathrm{~min}$, twice in Tris buffer $(0.1 \mathrm{~m}$ Tris- $\mathrm{HCl}, \mathrm{pH} 7.5$, and $0.15 \mathrm{M} \mathrm{NaCl})$ and once in TNT buffer. The tyramide signal amplification involved deposition of biotinylated tyramide and was performed by incubating the sections for $10 \mathrm{~min}$ at room temperature with a 1:50 dilution of biotinyl tyramide (NEN) in $1 \times$ amplification diluent (Renaissance kit). After three washes, in Tris buffer (twice) and TNT buffer (once), the chromogenic detection of the deposited biotin was performed by incubation for $30 \mathrm{~min}$ at room temperature with fluorescein-conjugated streptavidin (Amersham) diluted at 1:200 in TNB buffer. Finally, the sections were rinsed extensively in Tris buffer and then mounted in a mixture of glycerol and PBS (3:1) containing $0.1 \%$ p-phenylenediamine (Sigma) (Johnson and Nogueira Araujo, 1981; Platt and Michael, 1983).

After processing, the sections were examined in a Nikon fluorescence microscope equipped with an oil dark-field condenser, a KP500 excitation filter, and an LP 520 stop filter. Photographs were taken on blackand-white Kodak Tri-X film (Kodak) or color film (Kodak Ektachrome $400 \mathrm{X}$ ). For confocal microscopy, samples were recorded using a Zeiss (Oberkochen, Germany) LSM410 with a $63 \times / 1.4$ NA objective using 488 $\mathrm{nm}$ excitation. Approximately 30 optical slices of $0.5 \mu \mathrm{m}$ thickness were sampled and combined to produce composite confocal images, which were printed on a Codonics NP-1600 photographic network printer (Codonics Inc., Middleburg Heights, $\mathrm{OH}$ ). 

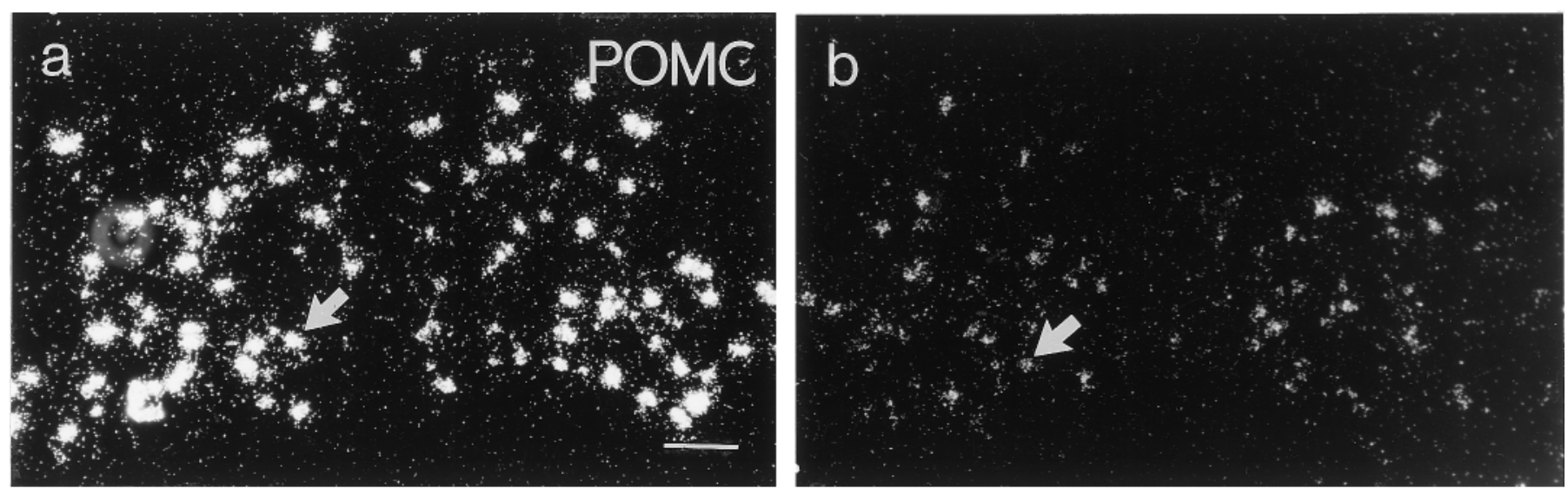

Figure 1. Dark-field micrograph of the arcuate nucleus from a wild-type $(a)$ and an anx/anx $(b)$ mouse after hybridization for POMC mRNA. Note fewer silver grains over individual cell profiles (arrows) in the mutant animal. Scale bar, $50 \mu \mathrm{m}$.
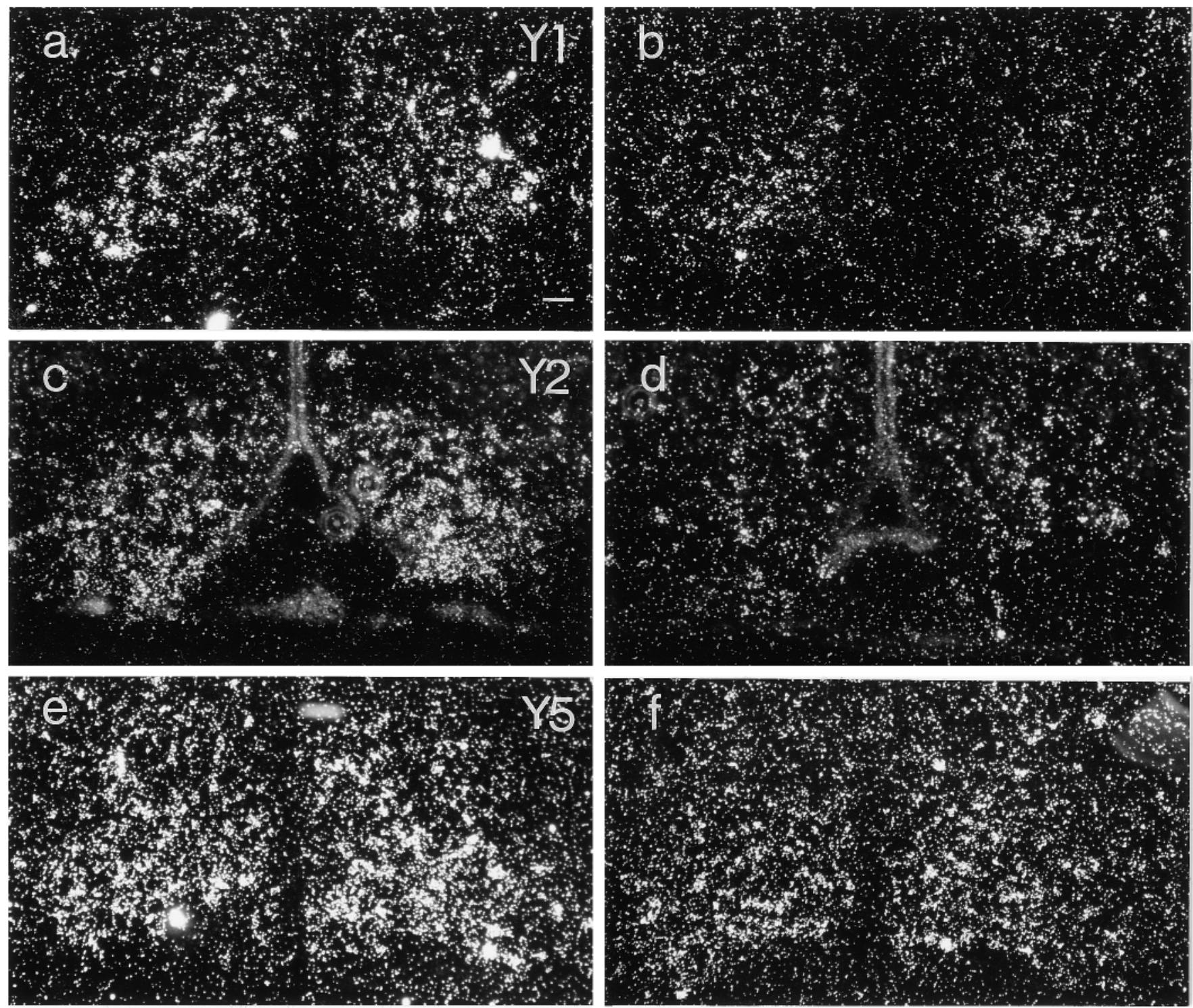

Figure 2. Dark-field micrographs of arcuate nuclei from wild-type $(a, c, e)$ and anx/anx $(b, d, f)$ mice after hybridization for Y1R $(a, b)$, Y2R $(c, d)$, and Y5R $(e, f)$ mRNAs. There is an attenuation of signal for all three mRNAs in mutant animals. Scale bar, $50 \mu \mathrm{m}$. 


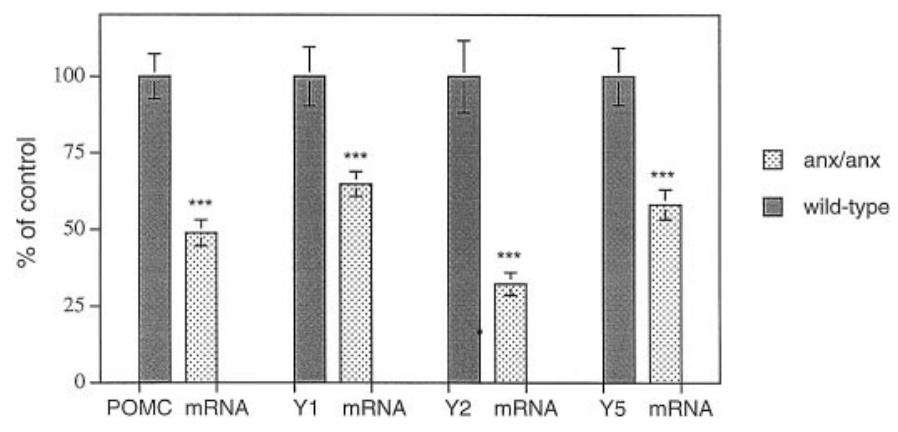

Figure 3. Relative POMC, Y1R, Y2R, and Y5R mRNA levels in wildtype ( filled bars) and anx/anx (stippled bars) mice, as measured by quantitative autoradiography. Levels of all four mRNA transcripts are significantly lower in mutant mice. Statistical analysis was performed by using ANOVA and Mann-Whitney $U$ test. ${ }^{* * *} p<0.001$.

Quantification of immunohistochemically labeled structures. For quantification of ACTH- and Y1R-IR cell bodies, coronal brain sections from both anx/anx mice and wild-type littermates at the level of bregma -1.9 $\mathrm{mm}$ were selected. The total number of stained cell bodies within the arcuate nucleus was counted at $20 \times$ magnification. For quantification of $\alpha$-MSH-IR nerve terminal arborizations, the periventricular area at the level of the suprachiasmatic nucleus (bregma -0.3) was selected. A grid (Graticules Ltd, Tonbridge, UK), with a $1.0 \mathrm{~mm}$ side length of individual squares, was placed in the eyepiece. The total number of crossings between fibers and grid lines within the field of view were counted in sections from both anx/anx mice and wild-type littermates through a $20 \times$ objective.

Statistical test. Statistical analysis was performed using ANOVA and Mann-Whitney $U$ test. All data are presented as mean \pm SD.

Controls. For the control for specificity in in situ hybridization, an excess $(100 \times)$ of unlabeled probe was added to the hybridization cocktail.
For immunohistochemistry, antiserum was preabsorbed with cognate peptide $\left(10^{-6} \mathrm{M}\right)$ before tissue incubation.

\section{RESULTS}

The anx/anx mice used in this study could be clearly distinguished from their control littermates phenotypically (also confirmed with genotyping), characterized by emaciation, particularly apparent on the tail where individual vertebrae could easily be delineated, hyperactivity, tremor, and uncoordinated gait. The average body weight of these animals was reduced by $>50 \%$ (wild-type, $10.2 \pm$ $0.2 \mathrm{gm}$; anx/anx, $4.5 \pm 0.1 \mathrm{gm} ; p<0.001$ ), and at dissection, an almost complete absence of abdominal adipose tissue was noted.

A distinct autoradiographic POMC mRNA signal could be visualized in the arcuate nucleus of wild-type mice (Fig. 1a). In anx/anx mice, this labeling was markedly decreased $(48.9 \pm 4.2 \%$ of wild-type mRNA levels; $p<0.001$ ) (Fig. 1, compare $a, b$; Fig. 3). The decrease in POMC expression was at least partly caused by decreased expression within individual cells. A reduction in the number of POMC mRNA-labeled cell bodies in the arcuate nucleus at the level of bregma $-1.7 \mathrm{~mm}$ was also seen in anx/anx mice $(54.8 \pm 11.2 \%$ of wild-type; $p<0.001)$.

Hybridization signal for both Y1R, Y2R, and Y5R mRNAs was observed in the arcuate nucleus (Fig. 2a-f). Y1R and Y5R mRNAs had similar distributions, predominantly in the ventrolateral portion of the nucleus, whereas Y2R mRNA was restricted to the ventromedial portion. Decreases in autoradiographic signal could be observed and quantified for all three receptor mRNAs in anx/anx mice, by approximately two-thirds for Y2R mRNA (32.9 $\pm 3.7 \%$ of wild-type mRNA levels; $p<0.001)$ (Fig. 2, compare $c, d$; Fig. 3) and approximately one-third for Y1R $(64.9 \pm 4.0 \%$ of wild-type mRNA levels; $p<0.001)$ (Fig. 2,
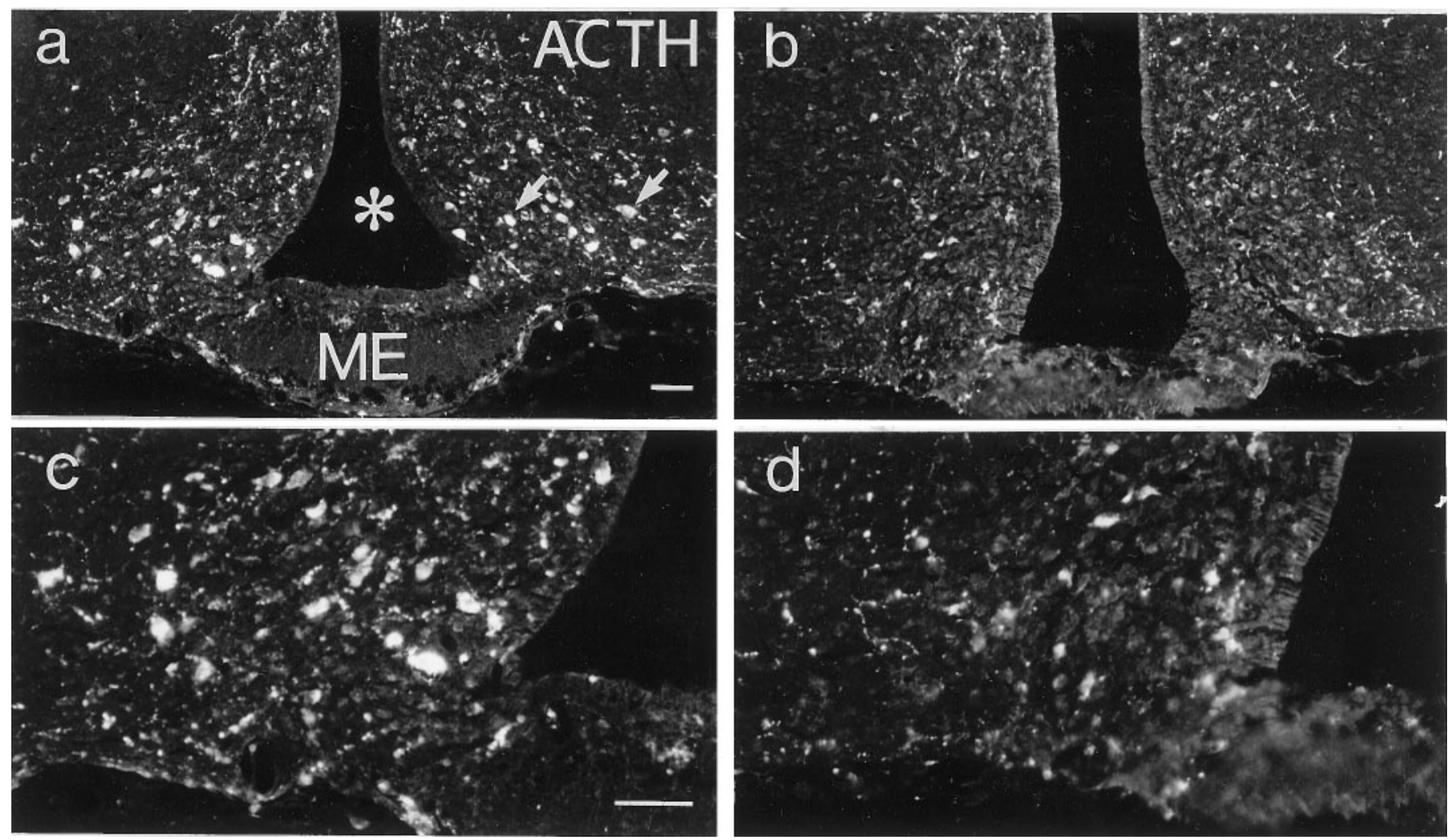

Figure 4. Fluorescence micrographs of sections from the arcuate nucleus of a wild-type $(a, c)$ and an anx/anx $(b, d)$ mouse stained with antiserum against ACTH. The number of ACTH-IR cell bodies (a, arrows) is reduced in mutant mice. $c$ and $d$ represent a higher magnification of $a$ and $b$, respectively. Asterisk indicates third ventricle. $M E$, Median eminence. Scale bars: (in $a$ ), $a, b, 50 \mu \mathrm{m}$; (in $c) c, d, 50 \mu \mathrm{m}$. 

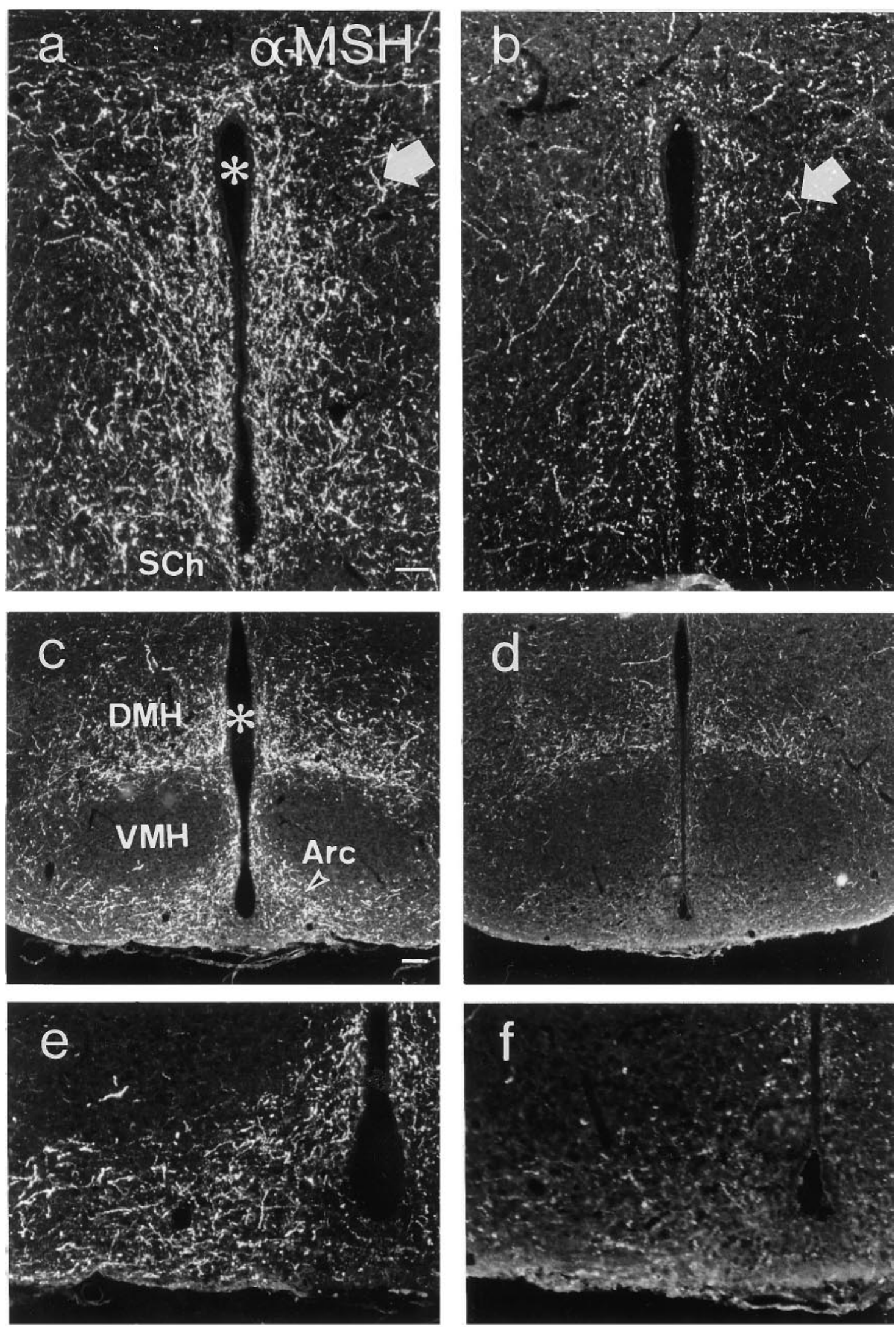

Figure 5. Fluorescence micrographs of sections from the periventricular area $(a, b)$ and arcuate nucleus $(c-f)$ of wild-type $(a, c, e)$ and anx/anx $(b, d$, $f$ ) mice stained with antiserum against $\alpha$-MSH. The number of $\alpha$-MSH-IR terminals (arrows) are reduced in mutant mice. $e$ and $f$ represent a higher magnification of $c$ and $d$, respectively. Asterisk indicates third ventricle. Arc, Arcuate nucleus; $D M H$, dorsomedial hypothalamic nucleus; SCh, suprachiasmatic nucleus; $V M H$, ventromedial hypothalamic nucleus. Scale bars: (in $a$ ) $a, b, e, f, 50 \mu \mathrm{m}$; (in $c$ ) $c, d, 100 \mu \mathrm{m}$. 
A

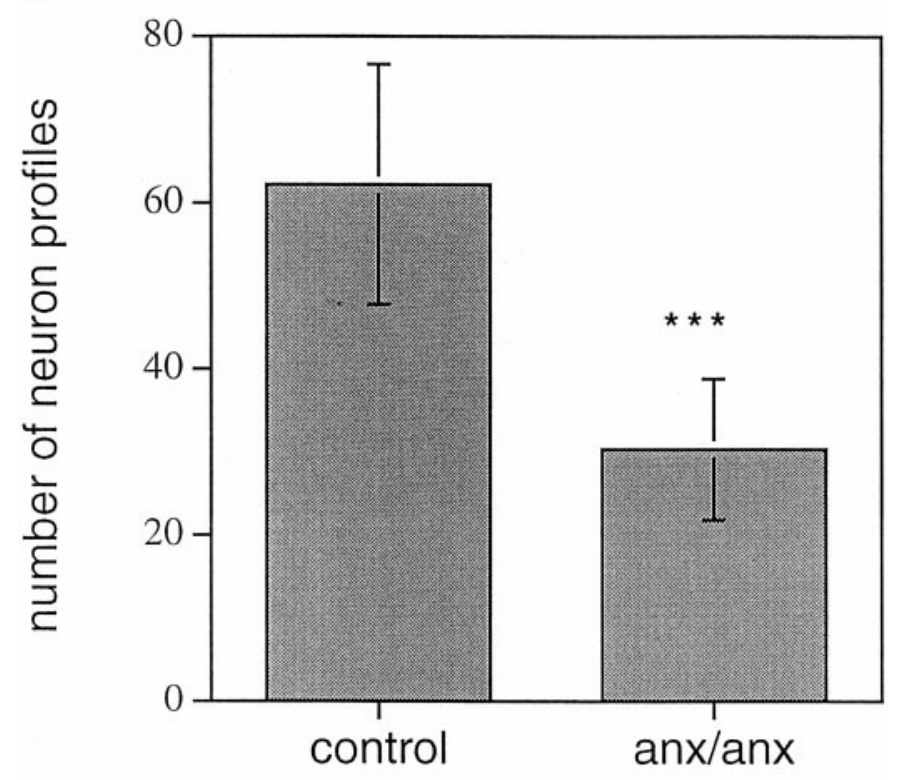

B

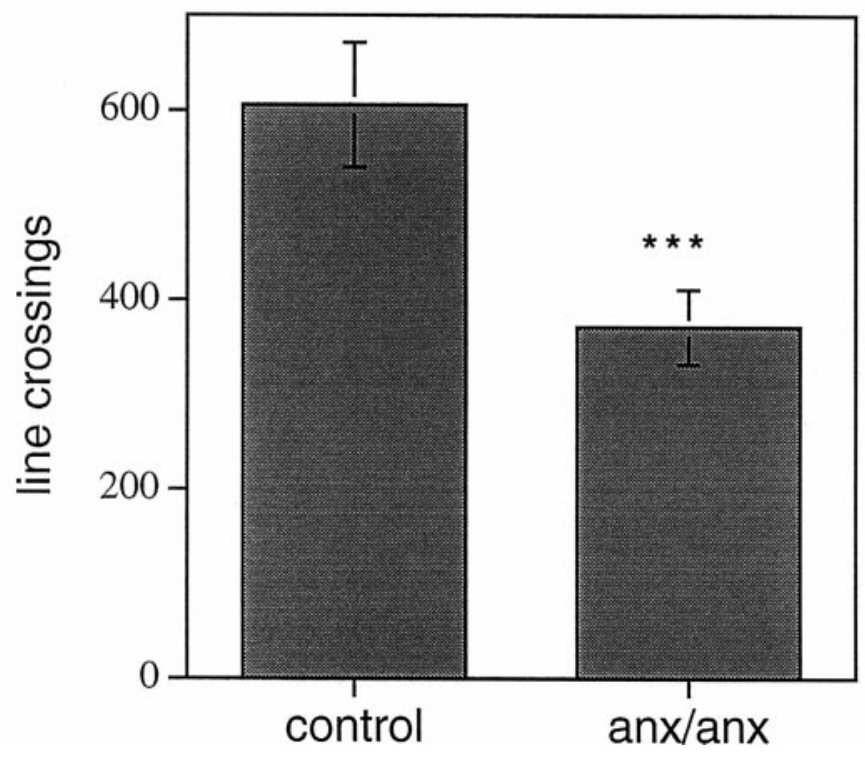

Figure 6. $a$, Quantification of the number of ACTH-IR neuron profiles in the arcuate nucleus. There is a significant reduction in the number of stained profiles in anx/anx mice compared with wild-type controls. $b$, Density of $\alpha$-MSH-IR terminals in the periventricular area of anx/anx compared with wild-type mice. Density was quantified as the number of crossings between the lines of a grid inserted in the microscope eyepiece and stained terminals. The number of line crossings is significantly reduced in mutant mice. Statistical analysis was performed by using ANOVA and Mann-Whitney $U$ test. ${ }^{* * *} p<0.001$.

compare $a, b$; Fig. 3$)$ and Y5R $(58.3 \pm 4.9 \%$ of wild-type mRNA levels; $p<0.001$ ) (Fig. 2, compare $e$, f; Fig. 3).

ACTH-like immunoreactivity (-LI) was seen in cell bodies of the ventrolateral portion of the arcuate nucleus of both anx/anx and wild-type mice (Fig. 4a-d) and in a limited number of varicose axons in areas in which $\alpha$-MSH-LI could be detected (see below). The number of stained cell bodies was decreased in anx/anx mice $(48.8 \pm 3.8 \%$ of wild-type; $p<0.001)$ (Figs. 4 , compare $a, c$, with $b, d$, respectively; Fig. 6).

$\alpha$-MSH-IR terminals could be observed in many nuclei, includ- ing the preoptic area, periventricular zone, paraventricular thalamic and hypothalamic nuclei, dorsomedial hypothalamic nucleus, and the arcuate itself (Fig. 5a-f); however, no arcuate cell bodies exhibiting $\alpha$-MSH-LI were seen. In anx/anx mice, the density of terminal arborizations was notably attenuated (Fig. 5, compare $a, c, e$ with $b, d, f$, respectively). Fiber density was quantified in the periventricular zone at the level of the suprachiasmatic nucleus and was found to be significantly decreased in anx/anx mice $(61.3 \pm 6.5 \%$ of wild-type; $p<0.001)$ (Fig. $6 b)$.

In wild-type animals, Y1R-LI was observed in the ventrolateral arcuate nucleus, decorating the cytoplasm and dendrites of large polygonal cells (Fig. 7a, $)$ ). The rich dendritic arborization observed in control mice was distinctly less pronounced in anx/anx mice and was almost completely absent in approximately half of the mutant mice (Fig. 7, compare $a, c$ with $b, d$ ). Furthermore, the number of stained cell bodies also appeared to be decreased, although this reduction was more variable $(60.7 \pm 30.8 \%$ of wild-type). Similar changes could also be observed in Y1R-IR cells of the paraventricular hypothalamic nucleus (Fig. 8, compare $a, c$ with $b, d$ ).

Autoradiographic signal after in situ hybridization was abolished if an excess of the cognate unlabeled oligonucleotide probe was added to the hybridization cocktail. The histochemical staining patterns described above could not be observed after incubation of antisera with corresponding peptide before tissue incubation.

\section{DISCUSSION}

The present study investigated the morphology and histochemistry of arcuate POMC neurons in a genetic model of hypophagia, the anx/anx mouse. Mutant mice displayed decreased levels, not only of POMC mRNA, but also of Y1R and Y5R mRNAs, which are expressed in the POMC neurons. In addition, morphological characteristics of POMC neurons were also affected, as seen with immunohistochemical markers: thus, the number of ACTH-IR cell bodies, as well as $\alpha$-MSH-IR terminals was decreased, and, furthermore, a dramatic reduction of dendritic extensions of the arcuate Y1R-IR cells [primarily corresponding to POMC cells (Broberger et al., 1997b; Fuxe et al., 1997)] was seen, as determined by staining with Y1R antiserum. In the arcuate neurons, $\mathrm{ACTH}$, after being cleaved from the POMC precursor, is further processed to $\alpha$-MSH (Watson and Akil, 1980; Khachaturian et al., 1985). The ratio of $\alpha-\mathrm{MSH} / \mathrm{ACTH}$ in the brain gradually increases with the distance from the arcuate cell bodies (Barnea et al., 1979). Thus, it could be expected that antiserum directed against the intact ACTH segment would predominantly stain cell bodies and, only to a lesser extent, terminals. In contrast, antiserum directed against $\alpha$-MSH would be more likely to stain terminals, all in accordance with the results shown here. It has been demonstrated that the concentrations of $\alpha$-MSH-LI in the brain are 4-15 times higher than those of ACTH-LI (Mezey et al., 1985).

Our previous studies on the anx/anx mouse have demonstrated altered histochemistry of arcuate NPY-AGRP coexpressing neurons (Broberger et al., 1997a, 1998b). However, it is important to note that the changes occurring in the NPY-AGRP population are distinct from those seen in POMC cells (present paper). Thus, the decreases in NPY-AGRP terminals are paired with increased cell body staining for these peptides, and NPY-AGRP mRNA levels remain unaffected in anx/anx mice. In contrast, the histochemical features of arcuate POMC neurons in anx/anx mice were characterized by decreased mRNA levels for all markers 

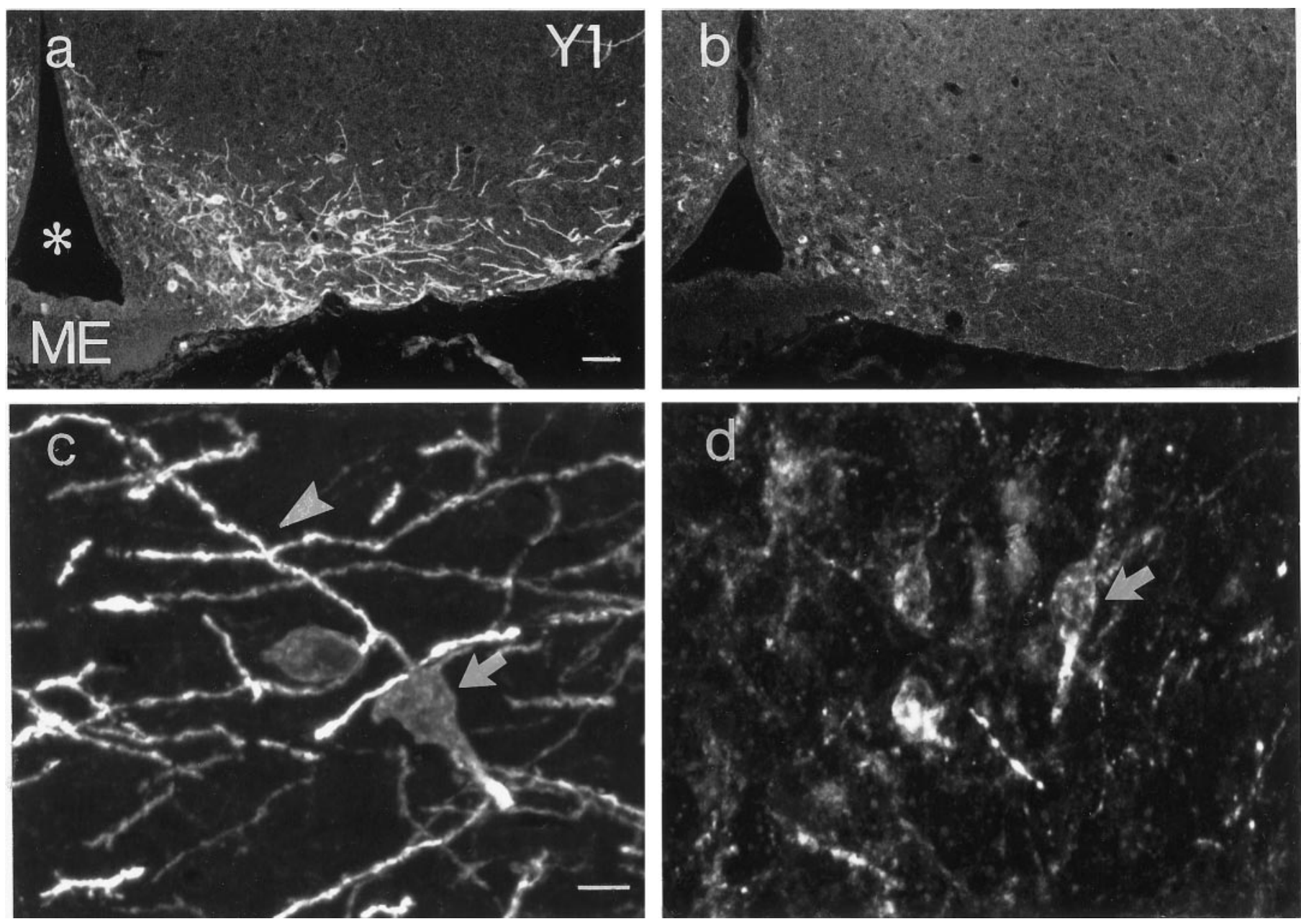

Figure 7. Fluorescence $(a, b)$ and confocal $(c, d)$ micrographs of sections from the arcuate nucleus of a wild-type $(a, c)$ and an anx/anx $(b, d)$ mouse stained with antiserum against the Y1R. Note dramatic reduction in dendritic arborizations (arrowheads), as well as attenuation in fluorescence and number of cell bodies (arrows) in anx/anx mice. Asterisk indicates third ventricle. ME, Median eminence. Scale bars: (in $a$ ) $a, b, 50 \mu \mathrm{m}$; (in $c$ ) $c, d, 10 \mu \mathrm{m}$.

studied, as well as decreased markers for both cell body and dendritic and axonal arborizations, suggestive of atrophy. One speculative explanation to account for these changes is that some molecule(s) secreted from the NPY cells may act as a trophic signal for POMC neurons and that POMC cells deterioratedegenerate in the absence of this signal. Alternatively, synaptic signaling contributed by NPY terminals may be necessary for the survival of POMC neurons.

There is good evidence for an antagonistic relationship between the arcuate NPY and POMC populations. Recent studies suggest that NPY neurons may regulate POMC signaling in several ways. POMC cell bodies and dendrites are lined by Y1Rs (Broberger et al., 1997b; Fuxe et al., 1997) and possibly also Y5Rs (Gerald et al., 1996; Naveilhan et al., 1998a) [which may be explained by the proximity of the two genes within the same transcriptional region (Herzog et al., 1997)], both of which couple to inhibitory G-proteins (Herzog et al., 1992; Larhammar et al., 1992; Wahlestedt and Reis, 1993). Also, NPY neurons coexpress AGRP (Shutter et al., 1997; Broberger et al., 1998a,b; Hahn et al., 1998), which acts as an antagonist of melanocortins at the MC4 receptor (Ollmann et al., 1997) and may be released from terminals in close proximity to POMC terminals (Broberger et al., 1998b). Thus, through regulation on both the cell body and terminal levels, NPY may have the "upper hand" in its antago- nistic relationship with POMC neurons, with POMC derivatives serving primarily to counterbalance the orexigenic NPY signals in states of positive energy balance. It may be speculated that the presence of inflow from the NPY neurons, although inhibitory on POMC signaling itself, is necessary for the development of the POMC system. It is noteworthy that changes in Y1R immunostaining, similar to those observed in the arcuate, could also be seen in cells in the paraventricular hypothalamic nucleus (present data). These Y1R-expressing cells also receive innervation from arcuate NPY neurons (Bai et al., 1985; Broberger et al., 1998b) but do not express POMC. This suggests that changes in the tone exerted by arcuate-derived NPY terminals, rather than the histochemical phenotype of the target cell, are of relevance for the morphological changes observed in hypothalamic Y1R-IR cells in anx/anx mice. This hypothesis remains to be validated experimentally, and to fully determine whether the NPY and POMC changes are interrelated may have to await molecular characterization of the anx gene. Furthermore, we have not in the present study investigated whether the brainstem POMC neurons, which also appear to modulate food intake (Grill et al., 1998), are affected in the anx/anx mouse.

The argument made above is based on the assumption that there is a de facto impairment in release of secreted molecules from the NPY neurons. It should be kept in mind, however, that 

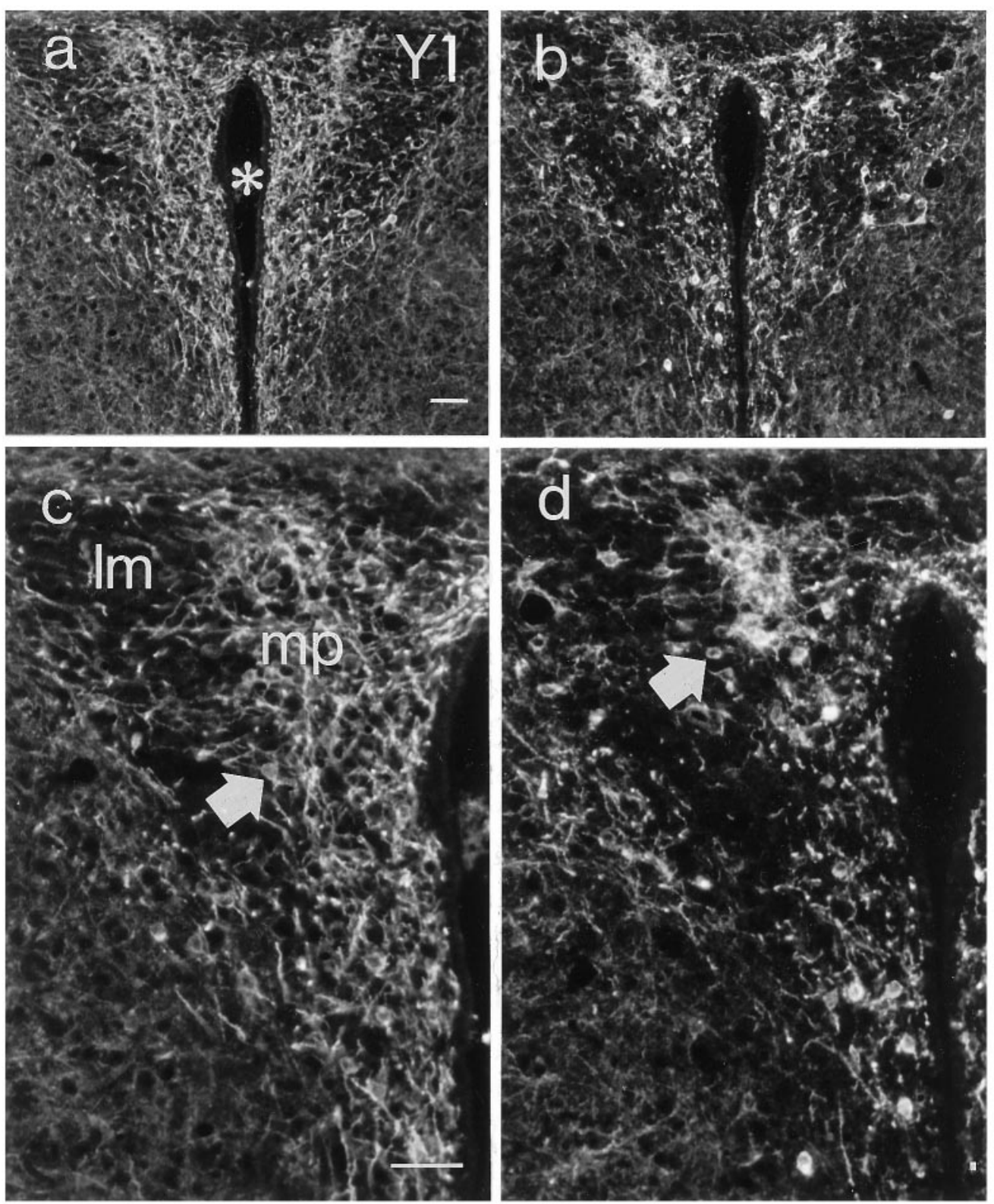

Figure 8. Fluorescence micrographs of sections from the paraventricular hypothalamic nucleus of a wild-type $(a, c)$ and an anx/anx $(b, d)$ mouse stained with antiserum against the Y1R. (Micrographs in $a$ and $b$ are magnified in $c$ and $d$, respectively). There is a reduction in both cell bodies (arrows) and dendritic arborizations. Asterisk indicates third ventricle. $m p$, Medial parvocellular nucleus; $I m$, lateral magnocellular nucleus. Scale bar, $50 \mu \mathrm{m}$. the changes in NPY histochemistry (Broberger et al., 1997a) are partly compatible also with a hypersecretion of NPY as an effect secondary to energy depletion, wherein the decreased terminal staining could be the result of increased release and the increased cell body staining the result of increased production of NPY. Yet, this view does not appear compatible with the normal arcuate NPY mRNA levels in the anx/anx mouse (Broberger et al., 1997a) (although it cannot be ruled out that translational and posttranslational mechanisms are affected in mutant mice). Starvation per se increases arcuate NPY mRNA (Brady et al., 1990) and also increases NPY staining in arcuate terminal fields (Calzá et al., 1989), contrary to what is seen in anx/anx mice.

In this context, it is also notable that, in the arcuate nucleus of mice lacking the NPY gene (Erickson et al., 1996), POMC expression is comparable with normal animals (Hohmann et al., 1998), and Y1R-LI is distributed in a normal pattern with richly arborized dendrites (C. Broberger, J. Erickson, R. Palmiter, and T. Hökfelt, unpublished observations). This would suggest that NPY itself is not necessary for the development of the POMC system. However, as mentioned above, the NPY neurons express several other messenger molecules, including AGRP (Broberger et al., 1998a,b; Hahn et al., 1998) and, in a subpopulation of NPY neurons, the GABA-synthesizing enzyme glutamic acid decarboxylase (Horvath et al., 1997). Likely, several other coexpressed molecules remain to be discovered, which may further explain how NPY neurons regulate the POMC cells. Finally, the possible involvement of $\beta$-endorphin, a POMC-derived peptide that, in contrast to the melanocortins, stimulates food intake when administered centrally (Grandison and Guidotti, 1977), remains to be investigated in the anx phenotype.

Microinjection of the Y2R agonist NPY(13-36) into the hypothalamic paraventricular nucleus inhibits food intake (Leibowitz and Alexander, 1991), and mice rendered deficient of the Y2R gene develop hyperphagia when fed a high-fat diet (Naveilhan et al., 1998b), indicating that the Y2R exerts an inhibitory tone on food intake. The Y2R is expressed in arcuate NPY neurons (Broberger et al., 1997b). Pharmacologically, this receptor has inhibitory properties, activating potassium currents and inhibiting 
calcium channels (Ewald et al., 1988; Chen and van den Pol, 1996; McQuiston and Colmers, 1996; Sun et al., 1998). Together, this suggests that the $\mathrm{Y} 2 \mathrm{R}$ may act as a presynaptic auto-inhibitory receptor (Wahlestedt et al., 1986). Combined with our previous demonstration of decreased hypothalamic NPY terminal staining in the anx/anx mouse (Broberger et al., 1997a), the present data may be interpreted as a compensatory downregulation of an auto-inhibitory mechanism in the absence of neurotransmitter release.

In summary, the results presented here demonstrate decreased labeling for all markers of arcuate POMC neurons so far studied, suggesting atrophy-degeneration of this population. In addition, we also demonstrate decreased mRNA levels for the Y2 receptor, which may be a response to decreased NPY transmission in this mutant. These data further delineate the hypothalamic abnormalities that may underlie the anx/anx phenotype.

\section{REFERENCES}

Bai FL, Yamano M, Shiotani Y, Emson PC, Smith AD, Powell JF, Tohyama M (1985) An arcuato-paraventricular and -dorsomedial hypothalamic neuropeptide Y-containing system which lacks noradrenaline in the rat. Brain Res 331:172-175.

Barnea A, Cho G, Porter JC (1979) Intracellular processing of alphaMSH and ACTH in hypothalamic neurons: a preliminary study. Soc Neurosci Abstr 5:523.

Brady LS, Smith MA, Gold PW, Herkenham M (1990) Altered expression of hypothalamic neuropeptide mRNAs in food-restricted and food-deprived rats. Neuroendocrinology 52:441-447.

Broberger C, Johansen J, Schalling M, Hökfelt T (1997a) Hypothalamic neurohistochemistry of the murine anorexia (anx/anx) mutation: Altered processing of neuropeptide Y (NPY) in the arcuate nucleus. J Comp Neurol 387:124-135.

Broberger C, Landry M, Wong H, Walsh J, Hökfelt T (1997b) Subtypes $\mathrm{Y} 1$ and $\mathrm{Y} 2$ of the neuropeptide $\mathrm{Y}$ receptor are respectively expressed in proopiomelanocortin and neuropeptide Y-containing neurons of the rat hypothalamic arcuate nucleus. Neuroendocrinology 66:393-408.

Broberger C, De Lecea L, Sutcliffe JG, Hökfelt T (1998a) Hypocretin/ orexin- and melanin-concentrating hormone-expressing cells form distinct populations in the rodent lateral hypothalamus: relationship to the neuropeptide $\mathrm{Y}$ and agouti gene-related protein systems. J Comp Neurol 402:460-474.

Broberger C, Johansen J, Johansson C, Schalling M, Hökfelt T (1998b) The neuropeptide Y/agouti gene-related protein (AGRP) brain circuitry in normal, anorectic, and monosodium glutamate-treated mice. Proc Natl Acad Sci USA 95:15043-15048.

Broberger C, Johansen I, Johansson C, Schalling M, Hökfelt T (1998c) Hypothalamic neuropeptide Y (NPY) Y1, Y2 and Y5 receptor histochemistry in the anorexia (anx/anx) mouse. Soc Neurosci Abstr 24:175.

Calzá L, Giardino L, Battistini N, Zanni M, Galetti S, Protopapa F, Velardo A (1989) Increase of neuropeptide Y-like immunoreactivity in the paraventricular nucleus of fasting rats. Neurosci Lett 104:99-104.

Chen G, van den Pol AN (1996) Multiple NPY receptors coexist in preand postsynaptic sites: inhibition of GABA release in isolated selfinnervating SCN neurons. J Neurosci 16:7711-7724.

Clark JT, Kalra PS, Crowley WR, Kalra SP (1984) Neuropeptide Y and human pancreatic polypeptide stimulate feeding behavior in rats. Endocrinology 115:427-429.

Csiffáry A, Görcs TJ, Palkovits M (1990) Neuropeptide Y innervation of ACTH-immunoreactive neurons in the arcuate nucleus of rats: a correlated light and electron microscopic double immunolabeling study. Brain Res 506:215-222.

Dagerlind A, Friberg K, Bean A, Hökfelt T (1992) Sensitive mRNA detection using unfixed tissue: combined radioactive and nonradioactive in situ hybridization histochemistry. Histochemistry 98:39-49.

Drouin J, Goodman HM (1980) Most of the coding region of rat ACTH $\beta$-LPH precursor gene lacks intervening sequences. Nature 288:610-613.

Elmquist JK, Elias CF, Saper CB (1999) From lesions to leptin: hypothalamic control of food intake and body weight. Neuron 22:221-232.

Erickson JC, Clegg KE, Palmiter RD (1996) Sensitivity to leptin and susceptibility to seizures of mice lacking neuropeptide Y. Nature 381:415-418.

Eva C, Keinänen K, Monyer H, Seeburg P, Sprengel R (1990) Molecular cloning of a novel $\mathrm{G}$ protein-coupled receptor that may belong to the neuropeptide receptor family. FEBS Lett 271:81-84.

Ewald DA, Sternweis PC, Miller RJ (1988) Guanine nucleotide-binding protein Go-induced coupling of neuropeptide $\mathrm{Y}$ receptors to $\mathrm{Ca}^{2+}$ channels in sensory neurons. Proc Natl Acad Sci USA 85:3633-3637.

Fan W, Boston BA, Kesterson RA, Hruby VJ, Cone RD (1997) Role of melanocortinergic neurons in feeding and the agouti obesity syndrome. Nature 385:165-168.

Flood JF, Morley JE (1989) Dissociation of the effects of neuropeptide $\mathrm{Y}$ on feeding and memory: evidence for pre- and postsynaptic mediation. Peptides 10:963-966.

Fuxe K, Tinner B, Caberlotto L, Bunnemann B, Agnati LF (1997) NPY Y1 receptor like immunoreactivity exists in a subpopulation of $\beta$-endorphin immunoreactive nerve cells in the arcuate nucleus: a double immunolabelling analysis in the rat. Neurosci Lett 225:49-52.

Gerald C, Walker MW, Criscione L, Gustafson EL, Batzi-Hartmann C, Smith KE, Vaysse P, Durkin MM, Laz TM, Linemeyer DL, Schaffhauser AO, Whitebread S, Hofbauer KG, Taber RI, Branchek TA, Weinshank RL (1996) A receptor subtype involved in neuropeptideY-induced food intake. Nature 382:168-171.

Grandison L, Guidotti A (1977) Stimulation of food intake by muscimol and $\beta$-endorphin. Neuropharmacology 16:533-536.

Grill HJ, Ginsberg AB, Seeley RJ, Kaplan JM (1998) Brainstem application of melanocortin receptor ligands produces long-lasting effects on feeding and body weight. J Neurosci 18:10128-10135.

Hahn TM, Breininger JF, Baskin DG, Schwartz MW (1998) Coexpression of Agrp and NPY in fasting-activated hypothalamic neurons. Nat Neurosci 1:271-272.

Herzog H, Hort YJ, Ball HJ, Hayes G, Shine J, Selbie LA (1992) Cloned human neuropeptide Y receptor couples to two different second messenger systems. Proc Natl Acad Sci USA 89:5794-5798.

Herzog H, Darby K, Ball H, Hort Y, Beck-Sickinger A, Shine J (1997) Overlapping gene structure of the human neuropeptide Y receptor subtypes $\mathrm{Y} 1$ and $\mathrm{Y} 5$ suggests coordinate transcriptional regulation. Genomics 4:315-319.

Hohmann IG, Clifton DK, Steiner RA (1998) Elevated galanin mRNA in NPY knockout mice. Soc Neurosci Abstr 24:53.

Horvath TL, Bechmann I, Naftolin F, Kalra SP, Leranth C (1997) Heterogeneity in the neuropeptide Y-containing neurons of the rat arcuate nucleus: GABAergic and non-GABAergic subpopulations. Brain Res 756:283-286.

Huszar D, Lynch CA, Fairchild-Huntress V, Dunmore JH, Fang Q, Berkemeier LR, Gu W, Kesterson RA, Boston BA, Cone RD, Smith FJ, Campfield LA, Burn P, Lee F (1997) Targeted disruption of the melanocortin-4 receptor results in obesity in mice. Cell 88:131-141.

Johnson GD, Nogueira Araujo GM (1981) A simple method of reducing the fading of immunofluorescence during microscopy. J Immunol Methods 43:349-350.

Kalra SP, Dube MG, Pu S, Xu B, Horvath TL, Kalra PS (1999) Interacting appetite-regulating pathways in the hypothalamic regulation of body weight. Endocr Rev 20:68-100.

Khachaturian HY, Lewis ME, Tsou K, Watson SJ (1985) $\beta$-Endorphin, $\alpha$-MSH, ACTH, and related peptides. In: Handbook of chemical neuroanatomy. GABA and neuropeptides in the CNS, Vol 4, (Björklund A, Hökfelt T, eds), pp 216-272. Amsterdam: Elsevier.

Larhammar D, Blomqvist AG, Yee F, Jazin E, Yoo H, Wahlestedt C (1992) Cloning and functional expression of a human neuropeptide Y/peptide YY receptor of the Y1 type. J Biol Chem 267:10935-10938.

Leibowitz SF (1995) Brain peptides and obesity: pharmacological treatment. Obes. Res. 3:573S-589S.

Leibowitz SF, Alexander JT (1991) Analysis of neuropeptide Y-induced feeding: dissociation of $Y_{1}$ and $Y_{2}$ receptor effects on natural meal patterns. Peptides 12:1251-1260.

Mains RE, Eipper BA, Ling N (1977) Common precursor to corticotropins and endorphins. Proc Natl Acad Sci USA 74:3014-3018.

Maltais LJ, Lane PW, Beamer WG (1984) Anorexia, a recessive mutation causing starvation in preweanling mice. J Hered 75:468-472.

McQuiston AR, Colmers WF (1996) Neuropeptide Y2 receptors inhibit the frequency of spontaneous but not miniature EPSCs in CA3 pyramidal cells of rat hippocampus. J Neurophysiol 76:159-168.

Mezey E, Kiss JZ, Mueller GP, Eskay R, O’Donohue TL, Palkovits M (1985) Distribution of the pro-opiomelanocortin derived peptides, an- 
drenocorticotropic hormone, $\alpha$-melanocyte-stimulating hormone and $\beta$-endorphin (ACTH, $\alpha$-MSH, $\beta$-End) in the rat hypothalamus. Brain Res 328:341-347.

Miller JA (1991) The calibration of ${ }^{35} \mathrm{~S}$ or ${ }^{32} \mathrm{P}$ with ${ }^{14} \mathrm{C}$-labeled brain paste or ${ }^{14} \mathrm{C}$-plastic standards for quantitative autoradiography using LKB Ultrafilm or Amersham Hyperfilm. Neurosci Lett 121:211-214.

Nakamura M, Aoki Y, Hirano D (1996) Cloning and functional expression of a cDNA encoding a mouse type 2 neuropeptide $\mathrm{Y}$ receptor. Biochim Biophys Acta 1284:134-137.

Nakamura M, Yokoyama M, Watanabe H, Matsumoto T (1997) Molecular cloning, organization and localization of the gene for the mouse neuropeptide Y-Y5 receptor. Biochim Biophys Acta 1328:83-89.

Nakanishi S, Inoue A, Kita T, Nakamura M, Chang ACY, Cohen SN, Numa S (1979) Nucleotide sequence of cloned cDNA for bovine corticotropin-beta-lipotropin precursor. Nature 278:423-427.

Naveilhan P, Hassani H, Neveu I, Ernfors P (1998a) Analyse of Y2 receptor functions by gene targeting. Soc Neurosci Abstr 24:626.

Naveilhan P, Neveu I, Arenas E, Ernfors P (1998b) Complementary and overlapping expression of $\mathrm{Y} 1, \mathrm{Y} 2$ and $\mathrm{Y} 5$ receptors in the developing and adult mouse nervous system. Neuroscience 87:289-302.

Ollmann MM, Wilson BD, Yang Y-K, Kerns JA, Chen Y, Gantz I, Barsh GS (1997) Antagonism of central melanocortin receptors in vitro and in vivo by agouti-related protein. Science 278:135-138.

Platt JL, Michael AF (1983) Retardation of fading and enhancement of intensity of immunofluorescence by $p$-phenylenediamine. J Histochem Cytochem 31:840-842.

Poggioli R, Vergoni AV, Bertolini A (1986) ACTH-(1-24) and $\alpha$-MSH antagonize feeding behavior stimulated by kappa opiate agonists. Peptides 7:843-848.

Roberts JL, Herbert E (1977) Characterization of a common precursor to corticotropin and $\beta$-lipotropin: identification of $\beta$-lipotropin peptides and their arrangement relative to corticotropin in the precursor synthesized in a cell-free system. Proc Natl Acad Sci USA 74:5300-5304.

Sawchenko PE (1998) Toward a new neurobiology of energy balance, appetite, and obesity: the anatomists weigh in. J Comp Neurol 402:435-441.

Schalling M, Seroogy K, Hökfelt T, Chai S-Y, HH, Persson H, Larhammar D, Ericsson A, Terenius L, Graffi J, Massoulié J, Goldstein M (1988) Neuropeptide tyrosine in the rat adrenal gland - immunohistochemical and in situ hybridization studies. Neuroscience 24:337-349.
Shutter JR, Graham M, Kinsey AC, Scully S, Lüthy R, Stark KL (1997) Hypothalamic expression of ART, a novel gene related to agouti, is up-regulated in obese and diabetic mutant mice. Genes Dev 11:593-602.

Stanley BG, Leibowitz SF (1985) Neuropeptide Y injected in the paraventricular hypothalamus: a powerful stimulant of feeding behavior. Proc Natl Acad Sci USA 82:3940-3943.

Stanley BG, Magdalin W, Seirafi A, Nguyen MM, Leibowitz SF (1992) Evidence for neuropeptide $\mathrm{Y}$ mediation of eating produced by food deprivation and for a variant of the $\mathrm{Y}_{1}$ receptor mediating this peptide's effect. Peptides 13:581-587.

Sun L, Philipson LH, Miller RJ (1998) Regulation of $\mathrm{K}^{+}$and $\mathrm{Ca}^{++}$ channels by a family of neuropeptide Y receptors. J Pharmacol Exp Ther 284:625-632.

Tatemoto K (1982) Neuropeptide Y: complete amino acid sequence of the brain peptide. Proc Natl Acad Sci USA 79:5485-5489.

Tatemoto K, Carlquist M, Mutt V (1982) Neuropeptide Y-a novel brain peptide with structural similarities to peptide $\mathrm{YY}$ and pancreatic polypeptide. Nature 296:659-660.

Wahlestedt C, Reis DJ (1993) Neuropeptide Y-related peptides and their receptors-are the receptors potential therapeutic drug targets? Annu Rev Pharmacol Toxicol 32:309-352.

Wahlestedt C, Yanaihara N, Håkanson R (1986) Evidence for different pre- and post-junctional receptors for neuropeptide $\mathrm{Y}$ and related peptides. Regul Pept 13:307-318.

Watson SJ, Akil H (1980) $\alpha$-MSH in rat brain: occurrence within and outside brain $\beta$-endorphin neurons. Brain Res 182:217-223.

Woods SC, Seeley RJ, Porte DJ, Schwartz MW (1998) Signals that regulate food intake and energy homeostasis. Science 280:1378-1383.

Young WSI (1990) In situ hybridization histochemistry. In: Handbook of chemical neuroanatomy. Analysis of neuronal microcircuits and synaptic interactions, Vol 8 (Björklund A, Hökfelt T, Wouterlood FG, Van den Pol AN, eds), pp 481-512. Amsterdam: Elsevier.

Zamboni I, De Martino C (1967) Buffered picric acid formaldehyde. A new rapid fixative for electron microscopy. J Cell Biol 35:148A.

Zhang X, Bao L, Xu Z-Q, Kopp J, Arvidsson U, Elde R, Hökfelt T (1994) Localization of neuropeptide Y Y1 receptors in the rat nervous system with special reference to somatic receptors on small dorsal root ganglion neurons. Proc Natl Acad Sci USA 91:11738-11742. 